\title{
Induksi Kalus Tanaman Kentang Dombu (Solanum tuberosum L.) Secara In Vitro Dengan Pemberian ZPT 2,4-D (Dichlorophenoxy Acetid Acid)
}

\section{(The In Vitro Callus Induction Of Dombu Potato (Solanum tuberosum L.) By The Addition Of The Plant Growth Regulator 2,4-D (Dichlorophenoxy Acetid Acid)}

\author{
Siti Ruspita Lestari R.Idris ${ }^{1^{*}}$, Asri Pirade Paserang ${ }^{1}$ \\ 1 Jurusan Biologi, Fakultas MIPA Universitas Tadulako Jl. Soekarno Hatta Km 9 Tondo, Palu 94117, Sulawesi Tengah, \\ Indonesia.
}

Keywords: Potato, Callus, PGR 2.4-D

Keywords: Kentang, Kalus, Zpt 2,4-D

* Coresponding Author : sitiruspitalestari@gmail.com

\begin{abstract}
This research was aimed to determine the effect of the PGR 2.4-D (Dichlorophenoxy Acetid Acid) in various concentrations on induceing callus of Dombu potato (Solanum tuberosum L.). This research was performed based on Completely Randomized Design (RAL) with 6 treatments and 3 times repetation, so there were 18 experiment units. Each experiment used 3 explants so as there were 54 explants. The combination of concentration of the tested PGR in the culture media were $\mathrm{T} 1=\mathrm{MS}_{0}+2.4-\mathrm{D} 0 \mathrm{ppm}$ (control), $\mathrm{T} 2=\mathrm{MS}_{0}+2.4-\mathrm{D} 0.5 \mathrm{ppm}, \mathrm{T} 3=\mathrm{MS}_{0}+$ 2.4-D $1 \mathrm{ppm}, \mathrm{T} 4=\mathrm{MS}_{0}+2.4-\mathrm{D} 1.5 \mathrm{ppm}, \mathrm{T} 5=\mathrm{MS}_{0}+2.4-\mathrm{D} 2 \mathrm{ppm}$ and $\mathrm{T} 6=\mathrm{MS}_{0}+2.4-$ D $2.5 \mathrm{ppm}$. The results showed that callus induction was appeared in the concentration of $1.0,1.5,2.0$, and $2.5 \mathrm{ppm}$. Callus was generally formed on the Day-8 after plantation. Callus color was mostly greenish transparent, callus texture was mostly crumb type, and callus formation percentage was almost $100 \%$. The best media for inducing the callus was in treatment T4 (1.5 ppm 2.4-D), it referred to the formed callus biomass.
\end{abstract}

\footnotetext{
Abstrak

Penelitian ini bertujuan menentukan pengaruh pemberian ZPT Dichlorophenoxy Acetid Acid (2,4-D) dalam menginduksi kalus pada kentang dombu (Solanum tuberosum L.). Penelitian ini dilakukan berdasarkan Rancangan Acak Lengkap (RAL) dengan 6 perlakuan dan setiap perlakuan diulang sebanyak 3 kali, sehingga terdapat 18 unit percobaan. Setiap satu percobaan menggunakan 3 eksplan sehingga terdapat 54 eksplan. Kombinasi konsentrasi ZPT yang diuji pada media kultur adalah $\mathrm{T} 1=\mathrm{MS}_{0}+2.4-\mathrm{D} 0 \mathrm{ppm}$ (kontrol), $\mathrm{T} 2=\mathrm{MS}_{0}+2.4-\mathrm{D} 0.5 \mathrm{ppm}, \mathrm{T} 3=$ $\mathrm{MS}_{0}+2.4-\mathrm{D} 1 \mathrm{ppm}, \mathrm{T} 4=\mathrm{MS}_{0}+2.4-\mathrm{D} 1.5 \mathrm{ppm}, \mathrm{T} 5=\mathrm{MS}_{0}+2.4-\mathrm{D} 2 \mathrm{ppm}$ dan $\mathrm{T} 6=\mathrm{MS}_{0}+2.4-\mathrm{D} 2.5 \mathrm{ppm}$. Parameter yang diamati adalah saat muncul kalus, warna kalus, tekstur kalus, berat kalus dan persentase pembentuk kalus. Hasil penelitian menunjukkan bahwa induksi kalus terjadi pada konsentrasi 1.0, 1.5, 2.0 dan $2.5 \mathrm{ppm}$. Kalus umumnya terbentuk pada hari ke 8 setelah tanam. warna kalusnya rata-rata bening kehijauan, tekstur kalus rata-rata bertipe remah dan persentase pembentuk kalus rata-rata hampir mencapai $100 \%$. Berdasarkan berat kalus yang terbentuk, media yang paling baik digunakan dalam menginduksi kalus adalah pada perlakuan T4(1.5ppm 2.4-D).
} 


\section{Latar Belakang}

Kentang (Solanum tuberosum L.) merupakan tanaman yang berasal dari pegunungan Andes di Bolivia dan Peru. Tanaman kentang adalah tanaman semusim yang berbentuk semak atau perdu, tanaman kentang biasanya menghasilkan bunga, buah dan biji serta dapat membentuk umbi di dalam tanah atau di udara. Kentang salah satu sayuran penghasil umbi dari famili Solanacea. Umbi kentang memiliki kandungan nurtisi yang baik yaitu protein, asam amino esensial, mineral dan beberapa unsur-unsur mikrolainnya. Kandungan

Nutrisi pada umbi kentang juga memiliki sumber vitamin $\mathrm{C}$ (asam askorbat), beberapa vitamin B (tiamin, niasin, vitamin $\mathrm{B} 6$ ) dan mineral $(\mathrm{P}, \mathrm{Mg}, \mathrm{K})$ (Cahyono, 1996). Kebutuhan konsumsi kentang di Indonesia mengalami peningkatan dari tahun 2011 ke tahun 2014 dan mengalami penurunan di tahun 2015. Badan Pusat Statistik (2016) menunjukkan produksi kentang meningkat dari tahun 2011 sebesar 0.95 juta ton, tahun 2012 sebesar 1.9 juta ton, tahun 2013 sebesar 1.12 juta ton dan tahun 2014 sebesar 1.34 juta ton. Produksi kentang mengalami penurunan pada tahun 2015 dengan nilai sebesar 1.21 juta ton. Menurut Nuraini (2016), Salah satu penyebab menurunnya produksi kentang adalah kualitas bibit yang kurang baik, rendahnya produktivitas disebabkan oleh rendahnya kualitas dan kuantitas benih kentang, kurangnya benih kentang bermutu, pengendalian hama dan penyakit tanaman kentang yang masih kurang, dan masih terbatasnya kultivar kentang yang sesuai untuk kebutuhan pasar dan lingkungan tumbuh.

Desa dombu adalah salah satu daerah penghasil kentang yang terletak pada ketinggian $\pm 1000 \mathrm{mdpl}$ Kec. Marawola Kab.Sigi Provinsi Sulawesi Tengah. Kentang dombu memiliki ukuran kecil, umbi yang berwarna kuning dan resisten terhadap penyakit. Masyarakat lokal melakukan pembudidayaan kentang dombu secara konvensional menggunakan umbi sebagai bibit. Namun budidaya kentang dombu masih sangat rendah hal ini disebabkan memakan waktu yang cukup lama untuk proses pembibitan sekitar 4 - 5 bulan. Untuk proses penanaman sampai pemanenan hanya memakan waktu 2 bulan dan hanya memperoleh hasil panen sekitar 15-100 kg. Permasalahan tersebut perlu ditangani agar produksi kentang dombu dapat lebih berkualitas (Halide, 2019).

Faktor yang dapat mempengaruhi kurangnya produksi kentang diantaranya pemakaian umbi bibit yang kurang baik. Perbanyakan tanaman melalui kultur jaringan dapat menghasilkan bibit bebas penyakit terutama virus. Penyediaan umbi bibit dapat dilakukan dengan teknik perbanyakan cepat melalui stek atau umbi mini dalam usaha memperoleh bibit dalam jumlah banyak dalam waktu singkat dan dalam keadaan terkontrol (Sutapradja, 2008).

Usaha yang dapat meningkatkan produksi kentang salah satunya dengan teknik kultur jaringan, dengan menggunakan umbi berkualitas baik. Mutu genetik dicirikan oleh tingkat kemunduran benih, viabilitas benih dan daya simpan benih, sedangkan mutu fisik mencakup tingkat keseragaman yang tinggi baik bentuk, warna, ukuran dan berat per jumlah atau volume (Arifin, dkk., 2014).

Kultur jaringan merupakan salah satu teknik dalam perbanyakan tanaman secara in vitro dalam kondisi yang aseptik. Keuntungan perbanyakan bibit melalui kultur jaringan antara lain memperoleh tanaman yang unggul dalam jumlah yang banyak dan seragam, selain itu dapat diperoleh biakan (mother stock) sehingga dapat digunakan sebagai bahan untuk perbanyakan selanjutnya (Lestari, 2011).

Zat Pengatur Tumbuh mempunyai peran yang sangat penting dalam mengatur pertumbuhan dan perkembangan eksplan dalam kultur jaringan. Pertumbuhan dan morfogenesis eksplan dalam kultur in vitro diatur oleh keseimbangan zat pengatur tumbuh pada media dengan hormon endogen yang terdapat dalam eksplan. penambahan zat pengatur tumbuh eksogen akan mengubah zat pengatur tumbuh endogen sel (Prastia, dkk., 2016). Penambahan 2.4-D dalam media akan merangsang pembelahan dan pembesaran sel pada eksplan sehingga dapat memacu pembentukan dan pertumbuhan kalus serta meningkatkan senyawa kimia alami flavonoid (Rahayu dkk., 2003).

Penelitian ini bertujuan untuk mengetahui pengaruh pemberian zpt 2,4-D (Dichlorophenoxy Acetid Acid) dengan berbagai konsentrasi dapat menginduksi kalus pada kentang dombu (Solanum tuberosum L.) secara in vitro.

\section{Bahan dan Metode}

Penelitian dilaksanakan di Laboratorium Kultur Jaringan Jurusan Biologi Fakultas Matematika dan IImu Pengetahuan Alam Universitas Tadulako. Penelitian ini menggunakan metode experimental yang disusun berdasarkan Rancangan Acak Lengkap (RAL) dengan 6 perlakuan dan setiap perlakuan diulang sebanyak 3 kali sehingga terdapat 18 unit percobaan. Setiap satu botol percobaan menggunakan 3 eksplan sehingga terdapat 54 eksplan. Perlakuan yang diujikan meliputi : 


$$
\begin{aligned}
& \mathrm{T} 1=\mathrm{MS}_{0}+2.4-\mathrm{D} 0.0 \mathrm{ppm} \\
& \mathrm{T} 2=\mathrm{MS}_{0}+2.4-\mathrm{D} 0.5 \mathrm{ppm} \\
& \mathrm{T} 3=\mathrm{MS}_{0}+2.4-\mathrm{D} 1.0 \mathrm{ppm} \\
& \mathrm{T} 4=\mathrm{MS}_{0}+2.4-\mathrm{D} 1.5 \mathrm{ppm} \\
& \mathrm{T} 5=\mathrm{MS}_{0}+2.4-\mathrm{D} 2.0 \mathrm{ppm} \\
& \mathrm{T} 6=\mathrm{MS}_{0}+2.4-\mathrm{D} 2.5 \mathrm{ppm}
\end{aligned}
$$

Alat-alat yang digunakan terlebih dahulu direndam khususnya botol kultur kemudian disterilisasi. Media yang digunakan dalam teknik kultur jaringan ini adalah media MS (Murashige \& Skoog). Bahan yang digunakan yaitu media MS instan, sukrosa, agar dan penambahan ZPT 2.4-D. Eksplan yang digunakan di sterilkan dengan menggunakan betadine. Eksplan yang telah steril dan telah dipotong per nodus, ditanam dalam media perlakuan.

\section{Hasil dan Pembahasan}

Pertumbuhan kalus ditunjukkan dengan adanya tonjolan kecil atau gumpalan-gumpalan sel pada eksplan berwarna putih, yang setiap harinya akan berubah bentuk dan warnanya. Rata-rata saat muncul kalus pada eksplan disajikan secara lengkap pada gambar 2 dan table 1. Respon perlakuan yang di ujikan tidak semua dapat menginduksi kalus. Pada perlakuan $T_{1}$ dan $T_{2}$ tidak ada respon pertumbuhan kalus, sedangkan pada perlakuan $T_{3}, T_{4}, T_{5}, T_{6}$ ada respon pertumbuhan kalus rata-rata $8 \mathrm{HST}$ dan warna kalusnya putih.

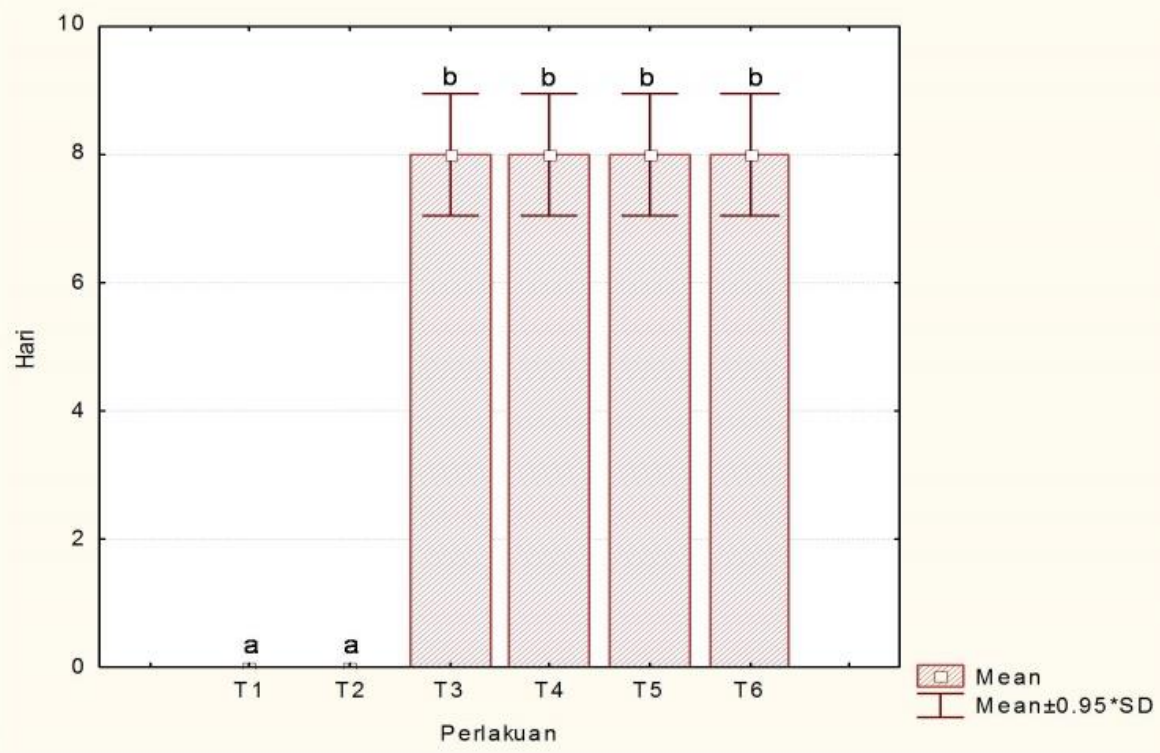

Gambar 1. Pengaruh konsentrasi 2.4-D sebagai perlakuan terhadap hari munculnya kalus. $\left(T_{1}=0 \mathrm{ppm}, \mathrm{T}_{2}=0.5 \mathrm{ppm}, \mathrm{T}_{3}=1 \mathrm{ppm}, \mathrm{T}_{4}=1.5 \mathrm{ppm}, \mathrm{T}_{5}\right.$ $=2 \mathrm{ppm}, \mathrm{T}_{6}=2.5 \mathrm{ppm}$ ).

Tabel 1. Warna kalus $S$. tuberosum L. pada berbagai perlakuan

\begin{tabular}{lccc}
\hline \multicolumn{1}{c}{ Perlakuan } & \multicolumn{3}{c}{ Ulangan } \\
\cline { 2 - 4 } Konsentrasi & 1 & 2 & 3 \\
\hline $\mathrm{T}_{1}(0 \mathrm{ppm})$ & - & - & - \\
$\mathrm{T}_{2}(0.5 \mathrm{ppm})$ & - & - & - \\
$\mathrm{T}_{3}(1 \mathrm{ppm})$ & Putih & Putih & Putih \\
$\mathrm{T}_{4}(1.5 \mathrm{ppm})$ & Putih & Putih & Putih \\
$\mathrm{T}_{5}(2 \mathrm{ppm})$ & Putih & Putih & Putih \\
$\mathrm{T}_{6}(2.5 \mathrm{ppm})$ & Putih & Putih & Putih \\
& kekuningan & & \\
\hline
\end{tabular}

Tabel 2. Tipe kalus $S$. tuberosum L. pada berbagai perlakuan

\begin{tabular}{lccc}
\hline Perlakuan & \multicolumn{3}{c}{ Ulangan } \\
\cline { 2 - 4 } Konsentrasi & 1 & 2 & 3 \\
\hline T1(0ppm) & - & - & - \\
T2(0.5ppm) & - & - & - \\
T3(1ppm) & Remah & Remah & Remah \\
T4(1.5ppm) & Remah & Remah & Remah \\
T5(2ppm) & Remah & Remah & Remah \\
T6(2.5ppm) & Intermediet & Remah & Remah \\
\hline
\end{tabular}



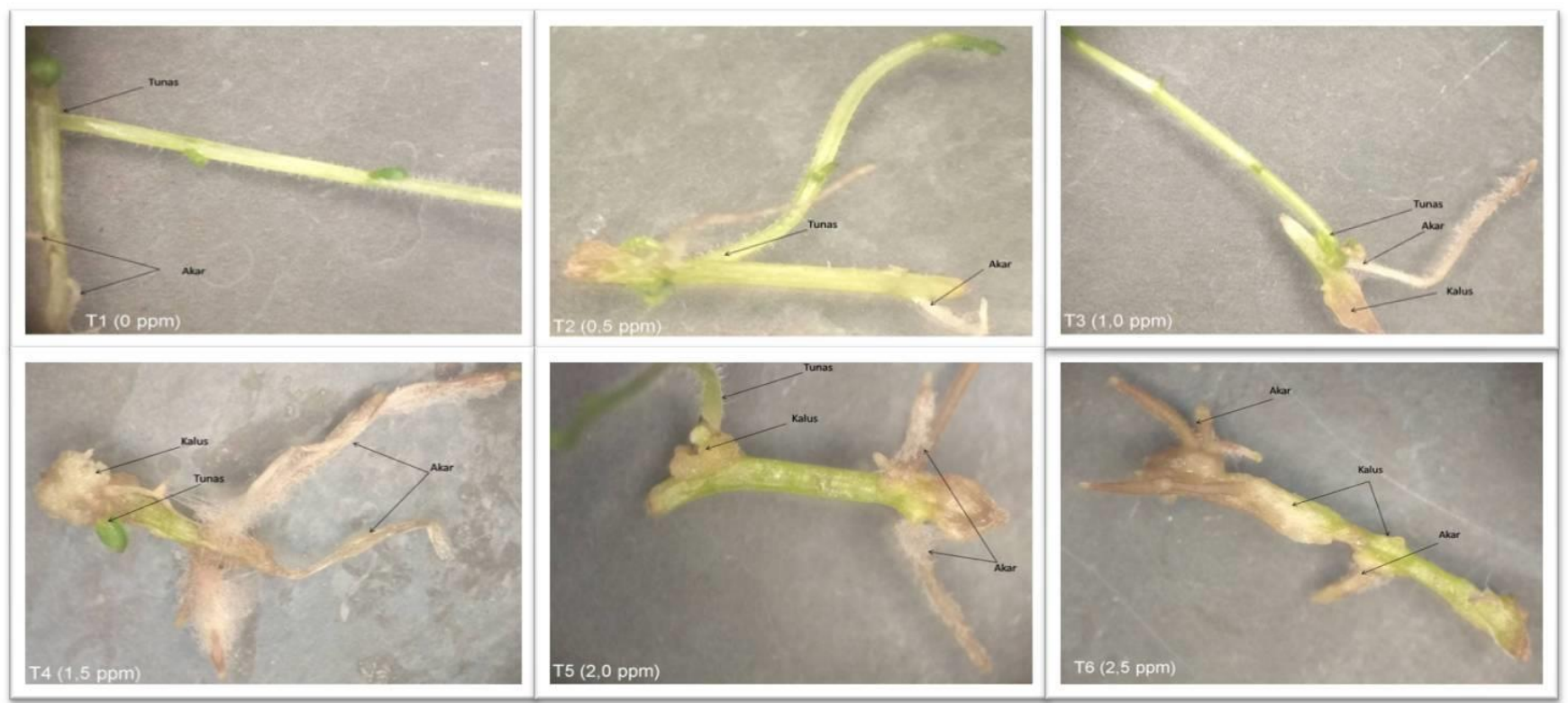

Gambar 2. Penampakan warna kalus $8 \mathrm{HST}\left(\mathrm{T}_{1}, \mathrm{~T}_{2}\right.$, tidak ada pertumbuhan kalus) dan $\left(T_{3}, T_{4}, T_{5}, T_{6}\right.$ bagian nampak pertumbuhan kalus)

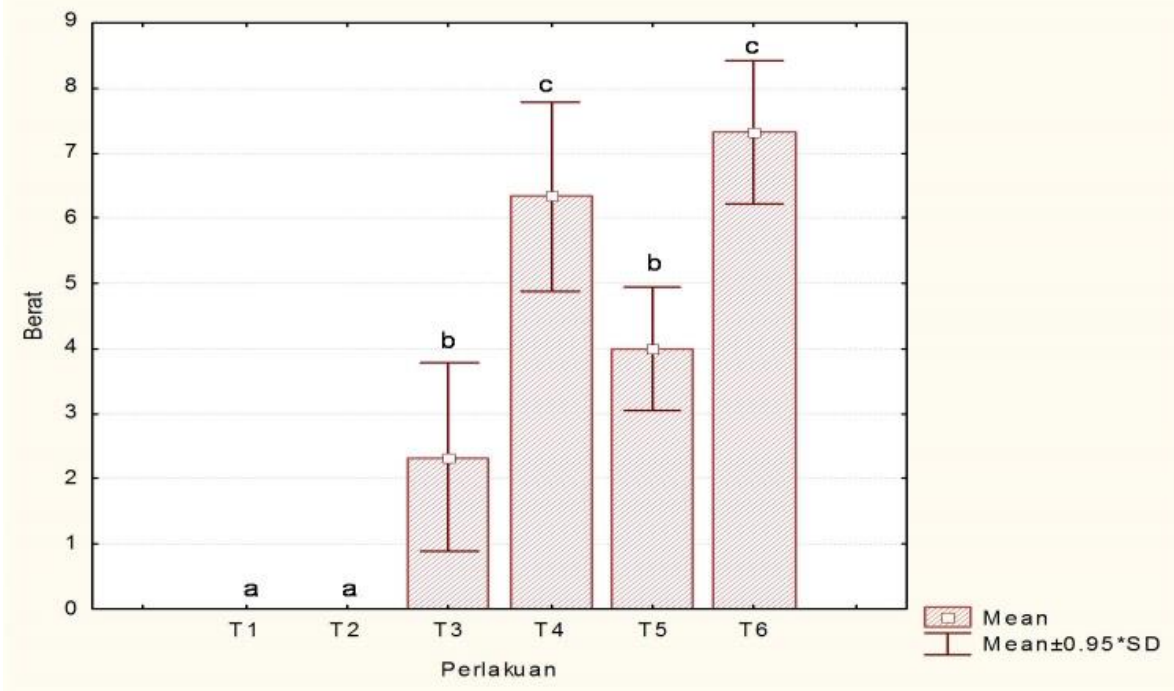

Gambar 3. Pengaruh konsentrasi 2.4-D pada media terhadap berat kalus. Hasil sidik ragam menunjukkan beda nyata. Bar menunjukkan nilai $\pm S D$.

Pembentukan atau pembengkakan kalus seragam pada perlakuan $T_{3}, T_{4}, T_{5}$, dan $T_{6}$ umur rata-rata 8 HST, sedangan pada perlakuan $T_{1}$ dan $T_{2}$ tidak menunjukkan adanya pertumbuhan kalus. Menurut Paserang, et al., (2015), melaporkan bahwa eksplan kotiledon muda tanaman jarak pagar mulai berkalus pada umur 14 hari setelah kultur. Sedangkan pada tanaman model tembakau dibutuhkan waktu 10-14 hari untuk pembentukan kalus (Paserang, et al., 2016). Tetapi semua perlakuan dari $T_{1}, T_{2}, T_{3}, T_{4}, T_{5}$ dan $T_{6}$ dengan pemberian ZPT 2.4-D berhasil merangsang proses pertumbuhan tunas. Pada uji perlakuan $T_{2}$ dengan pemberian zpt 2.4-D 0,5 ppm tidak dapat menginduksi kalus karena konsentrasinya terlalu rendah. Menurut Winarto, et al., (2010), persentase untuk pembentukan tunas, kombinasi terbaiknya adalah 2.4-D $0.5 \mathrm{mg} / \mathrm{l}$ dan TDZ $1.0 \mathrm{mg} / \mathrm{l}$. Pemberian kombinasi perlakuan zpt pada media MS memberikan hasil yang baik karena adanya kerja sama antara auksin dan sitokinin dalam menginduksi tunas, hal ini seperti pernyataan Werner (2009), eksplan yang diinokulasikan pada medium dengan kombinasi auksin dan sitokinin mampu menginduksi tunas. Terbentuknya tunas dan kalus pada perlakuan merupakan bukti, 
bahwa sel-sel mampu merespon zpt 2.4-D yang diberikan secara kombinasi. Abiding (1990), menyatakan ZPT pada konsentrasi tertentu mampu menghambat kerja hormon dan dapat mengganggu perumbuhan dan perkembangan sel.

Berdasarkan pengamatan morfologi, hasil analisis deskriftif warna kalus yang terjadi pada eksplan tanaman kentang dombu yaitu berwarna putih kehijauan dan putih kekuningan. Kalus muda berwarna putih, kemudian warnanya akan berubah menjadi hijau dengan bertambahnya umur. Perbedaan warna kalus ini disebabkan adanya perubahan pigmentasi (Harjoko, 1999). Hasil pengamatan warna kalus dari eksplan tanaman kentang dombu tersebut disajikan dalam Tabel 1. Indikator perkembangan eksplan pada budidaya in vitro berupa warna kalus, merupakan gambaran visual kalus sehingga dapat diketahui bahwa kalus yang terbentuk sel-selnya masih aktif membelah atau mati. Kalus yang terbentuk dari suatu eksplan biasanya memunculkan warna yang berbeda-beda. Beberapa pendapat mengatakan bahwa kalus yang berkualitas adalah kalus yang berwarna hijau. Menurut Fatmawati (2008), warna kalus mengindikasikan keberadaan klorofil dalam jaringan, sehingga semakin hijau warna kalus semakin banyak pula kandungan klorofilnya.

Berdasarkan pengamatan struktur kalus, hasil analisis destruktif struktur kalus yang terjadi pada eksplan tanaman kentang dombu menunjukkan bahwa kalus yang terbentuk adalah kalus yang bertekstur remah dan intermediet. Hasil pengamatan kalus yang terbentuk pada eksplan tanaman kentang dombu dapat dilihat pada Gambar 2 dan Tabel2. Hasil pengamatan menunjukkan adanya tipe kalus yang berbeda-beda, pada perlakuan $T_{3}, T_{4}, T_{5}$ menghasilkan tipe remah sedangkan pada perlakuan $\mathrm{T}_{6}$ menunjukkan tipe intermediet. Struktur kalus merupakan salah satu penanda kualitas suatu kalus. Kalus yang memiliki kualitas baik ditandai dengan struktur kalus yang remah (friable). Kalus yang remah biasanya mudah dalam hal pemisahan sel-selnya menjadi sel tunggal sedangkan kalus yang kompak selnya terlihat sangat kompak, sulit untuk dipisahkan dan sangat padat. Stuktur kalus dapat dibedakan atas kalus yang berstruktur kompak (non friable) dan kalus yang berstruktur remah (friable). Pierik (1987), menyatakan bahwa struktur pada kalus dapat bervariasi dari kompak hingga remah, tergantung pada jenis tanaman yang digunakan, komposisi nutrien media, zat pengatur tumbuh dan kondisi lingkungan kultur. Menurut
Widyawati (2010), terbentuknya kalus yang berstruktur remah dipacu oleh adanya hormon auksin endogen yang diproduksi secara internal oleh eksplan yang telah tumbuh membentuk kalus tersebut.

Berdasarkan pengamatan berat kalus, hasil analisis destruktif berat kalus yang terjadi pada eksplan tanaman kentang dombu menunjukkan bahwa kalus memiliki massa terberat adalah kalus yang pada perlakuan $T_{6}$ dan $T_{4}$ dengan rata-rata berat $7 \mathrm{mg}$ dan $6 \mathrm{mg}$. Menurut Sari dan Paserang (2019), menyatakan bahwa kalus pada kentang dombu yang memiliki massa paling berat adalah pada perlakuan T7 (kontrol) dengan rata-rata berat $27 \mathrm{mg}$. Berat basah yang dihasilkan sangat tergantung pada kecepatan sel-sel tersebut membelah diri, memperbanyak diri, dilanjutkan dengan membesarnya sel. Menurut Ruswaningsih (2007), berat segar secara fisiologi terdiri dari dua kandungan yaitu air dan karbohidrat. Indah dan Ermavitalini (2013), menyatakan bahwa berat segar kalus yang besar disebabkan kandungan air yang tinggi.

Berdasarkan hasil dari penelitian dapat disimpulkan bahwa pemberian berbagai konsentrasi zpt 2.4-D yang tepat terhadap kecepatan pertumbuhan dalam menginduksi kalus kentang dombu adalah T4 (1.5ppm 2.5-D) berdasarkan berat kalus yang terbentuk.

\section{Ucapan Dan Terimakasih}

Terimakasih kepada Riska Sari S.Si dan Lyly Zulraufianti yang telah membantu selama penelitian. Kepada direktorat penelitian dan pengabdian kepada masyarakat (DP2N) Kemenristekdikti yang telah mendanai sebagian penelitian dengan surat keputusan nomor 3/E/KPT/2018 kepada Dr. Asri Pirade Paserang, M.Si.

\section{Daftar Pustaka}

Abiding A., 1990, Dasar-dasar Pengetahuan tentang Zat Pengatur Tumbuh. Bandung : Penerbit Angkasa.

Arifin, M. S., Nugroho, A., dan Suryanto, A., 2014, Kajian Panjang Tunas Dan Bobot Umbi Bibit Terhadap Produksi Tanaman Kentang (Solanum tuberosum L.) Varietas Granola. Produksi Tanaman, 2 (April), 221-229.

Cahyono, B., 1996, Tanaman Kentang. CV Aneka, Solo.

Fatmawati, A., 2008, Kajian konsentrasi BAP dan 2,4-D terhadap induksi kalus tanaman Artemisia annua L. Secara in vitro. Skripsi Fakultas Pertanian 
UNS. Surakarta.

Halide E, S, HJ., 2019, Keragaman Genetik, Heritabilitas Dan Korelasi Antar Sifat Kentang (Solanum tuberosum L.) Yang Dibudidayakan Di Sulawesi. Skripsi. Fmipa, Universitas Tadulako, Palu.

Harjoko, D., 1999, Pengaruh Macam-macam Auksin terhadap Poliploidisasi Kalus Tanaman Semangka pada Kultur in Vitro. Surakarta: Fakultas Pertanian UNS. Hendaryono, D.P dan A. Wijayani. 1994. Teknik Kultur Jaringan. Yogyakarta: Kanisius.

Indah, P. N., dan Ermavitalini, D., 2013, Induksi Kalus Daun Nyamplung (Calophyllum inophyllum Linn.) pada Beberapa Kombinasi Konsentrasi 6Benzylaminopurine (BAP) dan 2,4Dichlorophenoxyacetic Acid (2,4-D). Jurnal Sains dan Seni Pomits. 2(1).

Karjadi, A. K. dan Buchory. A., 2008, Pengaruh Auksin Dan Sitokinin Terhadap Pertumbuhan Dan Perkembangan Jaringan Meristem Kentang Kultivar Granola. J. Hort, 18(4), 380-384.

Karjadi dan Buchory. (2008). Pengaruh Komposisi Media Dasar, Penambahan BAP, Dan Pikloram Terhadap Induksi Tunas Bawang Merah. J. Hort. 18(1): $1-9$

Lestari, E. G., 2011, Peranan Zat Pengatur Tumbuh Dalam Perbanyakan Tanaman Melalui Kultur Jaringan. AgroBiogen, 7(1), 63-68.

Paserang, A. P., Tjahjokkosono, A., Widyastuti, U., dan Suharsono, S., 2015, Transformation of Inhibitor of Meristem Activity (IMA) Gene in to Jatropha curcas L. Makara J. Sci. 19(3):117-222.

Paserang, A. P., Tjahjokkosono, A., Widyastuti, U., dan Suharsono, S., 2016, Transformation of Tobacco Plant Using Inhibitor of Meristem Activity (IMA) Genes. Pak. J. Biotecnol. 13(2):125-131.

Pierik, R. L. M., 1987, In Vitro culture of higher plant. Martinus Nijhoft Publisher. Netherlands.

Prastia, D. H., Hariyanto, dan Banowati, E., 2016, Pengaruh Pengetahuan Petani Kentang
Terhadap Pertanian Berkelanjutan Di Desa Kepakisan Kecamatan Batur, Edu Geogrphy, 4(3), 42-49.

Rahayu, B., Solichatun, dan Anggarwulan, E., 2003, Pengaruh Asam 2,4-Diklorofenoksiasetat (2,4-D) Terhadap Pembentukan Dan Pertumbuhan Kalus Serta Kandungan Flavonoid Kultur Kalus Kalus Acalypha indica L. Biofarmasi, 1(1), 1-6.

Ruswaningsih, F., 2007, Pengaruh Konsentrasi Ammonium Nitrat dan BAP Terhadap Pertumbuhan Eksplan Pucuk Artemisia annua L. Pada Kultur In Vitro. Skripsi Fakultas Pertanian UNS. Surakarta.

Sari, R., Paserang, A. P., Pitopang, R., dan Suwastika, I. N., 2019, Callus Induction of Potato (Solanum tuberosum L.) of c.v. Dombu In Vitro on MS Medium With Additional of Tomato Extract and Coconut Water. Natural Science: Journal of Science and technology Vol. 8. (1), 20-27.

Sutapradja, H., 2008, Pengaruh Jarak Tanam dan Ukuran Umbi Bibit Terhadap Pertumbuhan dan Hasil Kentang Varietas Granola Untuk Bibit. Hort, 18(2), 155-159.

Werner, T. dan Schmulling, T., 2009, Cytokinin Action in Plant Development. Current Opinion in Plant Biology 2009,12:527-538.

Widyawati, G., 2010, Pengaruh Variasi Konsentrasi NAA dan BAP Terhadap Induksi dan Pertumbuhan Kalus Jarak Pagar (Jatropha curcas L.). Tesis Program Pasca Sarjana UNS. Surakarta.

Winarto, B., Mattjik, N.A., Purwoto, B., 2010, Peningkatan pertumbuhan dan regenerasi eksplan hasil kultur Anther Anthuriu melalui perbaikan media kultur. J. Hort, 20(1):1-9.

Wulandari, A. N., Heddy, S., dan Suryanto, A., 2014, Penggunaan Bobot Umbi Bibit Pada Peningkatan Hasil Tanaman Kentang (Solanum tuberosum L.) G3 dan G4 Varietas Granola. Produksi Tanaman, 2(1), 65-72. 